\title{
Assessing Genetic Diversity of Rice Varieties under Drought Stress Conditions
}

\author{
Mina ABARSHAHR, Babak RABIEI, Habibollah SAMIZADEH LAHIGI \\ University of Guilan, Faculty of Agricultural Sciences, Agronomy and Plant Breeding Departament, \\ POBox41635-1314, Rasht, Iran; mina.abarshahr@gmail.com
}

\begin{abstract}
In order to compare different rice genotypes grown under drought stress conditions a field experiment was conducted. In this study thirty different genotypes of native, breeded and upland cultivars were evaluated. Analysis of variance showed significant differences among genotypes in respect of all vegetative and morphological traits. Genotypes were devided into three groups by cluster analysis based on all studied traits with minimum variance method (Ward's Method). The total average indicates significant differences among groups in respect of all morphological and physiological characteristics. In addition, eight drought stress tolerance indices including: sensitivity to stress index (SSI), drought response index (DRI), relative drought index (RDI), tolerance index (TOL), mean productivity index $(\mathrm{MP})$, stress tolerance index (STI), geometric mean productivity index (GMP) and harmonic mean index (HM) were calculated according to their grain yield under drought stress and normal conditions. In general, results of this experimnet revealed that, among rice cultivars 'Domsephid,' 'Deylamany', 'Hasansaraei,' 'Sadri,' 'Anbarboo' and 'Domsiah' had the highest sensitivity referring to drought stress and produced the lowest grain yield. Also, genotypes of 'IR24' (breeded of IRRI), 'Nemat,' 'Sephidroud', 'Kadoos' and 'Bejar (breeded of Iran) and 'Vandana', upland cultivar (originally from India) had the highest tolerance to drought stress and produced the highest grain yield. In conclusion, it was suggested that, these cultivars are suitable for drought stress conditions and are appropriate for hybridization with the aim of increasing drought tolerance.
\end{abstract}

Keywords: cluster analyse, drought stress, drought tolerance indices, rice

\section{Introduction}

From the beginning of agriculture, drought stress is one of the most important factors, causing famine and death by its influence on plant productions. There are five main reasons of the importance of drought stress; its unpredictablity, the way of occurance, intensity, time and duration of drought. On the other hand, interaction between drought stress and other abiotic stresses such as high temperature and changes in nutrition availability limits plant growth and development. Drought stress is a multidimensional stress that affects different plant growth stages. The impact of drought stress on total green plant surface and plant response to drought stress are very intricate, because it reflects combination of stress impacts and plant response in all essential levels of plant over time and place (Blum, 1996).

Drought stress or lack of water is not only limited to arid or semi arid areas, but also sometimes, due to irregular distribution of rain, causes unfavorable conditions for plant growth and development. It's obvious that drought stress causes significant decrease of plant yield (Kumar and Singh, 1998).

On the other hand, water supply, and also its shortages for irrigation, are the basic problems in crop production, especially rice. Furthermore, nowadays many meteorologists believe that even in rainy and fertile regions, which are suitable for paddy fields' establishment, like Giulan province in the North of Iran, lack of water will occure in the near future and this would be very hazardous for rice production. Genetic, molecular and physiological analysis help to identify components of drought resistance mechanisms, such as, the maximum of lost water through the plant, increase of water use efficiency, shortages of cell water tolerance and improving cell flexibility (Serraj et al., 2009). In cereals and especially rice, reproduction stages, including pollination and fertilization, are water critical and water deficit stress decrases significantly yield and yield components (Kumar Singh, 1998; Lafitte et al., 2003). Salekdeh et al. (2002) introduced a new mechanism as a response to drought stress by introducing a gradual drought stress during 23 days in two rice cultivars and proteomics analysis. Yield increase under drought stress conditions depends on the optimization of physiological process and mechanisms for avoiding water stress caused sympthons on the plant. On the other hand, when plant characteristics, such as maximum extraction of water by roots were measured, the efficiency of products improved in a dry environment (Janardhan and Krishnamoorthy, 1975; Reddy, 2009; Serraj et al., 2009). Fukai and Cooper (2001) classified the important mechanisms of rice function into three groups considering drought stress and its predictability: yield potential, phenology (drought escape) and drought tolerance. Oak et al. (2006) used drought re- 
sponse index (DRI) based on grain yield in order to study yield potential variety at flowering stage. They expressed that grain yield decreased in drought stress condition by $12 \%$ to $46 \%$. Breeding researchers can identify donor lines with high drought tolerance by the selection of DRI under conditions of drought stress (Pantuwan et al., 2002).

In order to study drought tolerance in wheat, 11 cultivars were studied by Siose Marde et al. (2006) and nine various indices were compared during the three years and in two places. They found that, under mild drought stress, mean productivity, geometric mean productivity and stress tolerance indices had the most ability to detect cultivars with high yield in both normal and drought stress conditions. Zhou et al. (2007) have been reported that, drought resistant genotypes can be determined by measuring some characteristics such as yield potential, delayed flowering, reduced plant height or DRI in both normal and drought stress conditions.

Since different rice cultivars have different responses to drought stress and there is too much genetic diversity among rice cultivars, regarding sensitivity and drought tolerance, this research has founded. The purpose of this study was the evaluation of drought stress influences on different rice cultivars and assessment of their tolerance and sensitivity in order to determine genetic distance and finally select the best suitable parents for hybridization in the breeding patterns.

\section{Materials and methods}

The experiment was carried out in the research farm, at the Faculty of Agricultural Sciences, University of Guilan, Guilan, Iran (49 $36^{\prime} \mathrm{E}$ longitude, $37^{\circ} 16^{\prime} \mathrm{N}$ latitude and $7 \mathrm{~m}$ altitude) during 2007 growing season. Although the average annual rainfall in this area is very high, but its general distribution does not coincide with rice growing stages, especially reproductive stages (from April to September) and the amount of rainfall is very low at this critical period, thus the crop is generally encountered by drought stress. Meteorological data related to the first 5 months of 2007 is shown in Tab. 1, while soil characteristics are presented in Tab. 2.

Rice seeds were obtained from Rice Research Institute, Rasht, Iran. The seeds were sown in nursery and then transplanted into the main land (cultivars' profiles of this experiment are given in Tab. 3). The experiment was performed in two different conditions (normal and drought stress) based on the randomized complete blocks design with three. The plots were about two meters apart from each other. In each experimental unit, there were 5 rows with final density 150 plants per square meters. After randomization of treatments to units, transplantation was performed, plant by plant. Irrigation was done till 20 days after transplantation in other word till full establishment of the seedlings. When plants were full established, drought stress was induced by irrigation withholding, while under normal conditions rice plants were irrigated completely till
Tab. 1. Meteorological data related to period of rice growth during the first 5 months of rice growing season in 2007

\begin{tabular}{|c|c|c|c|c|c|c|}
\hline \multirow{2}{*}{ Month } & \multirow{2}{*}{ 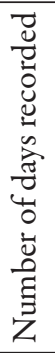 } & \multicolumn{2}{|c|}{ 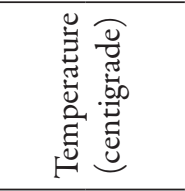 } & \multicolumn{2}{|c|}{ 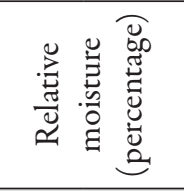 } & \multirow{2}{*}{ 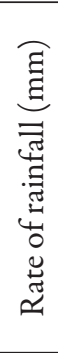 } \\
\hline & & 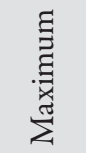 & $\underbrace{\Xi}$ & 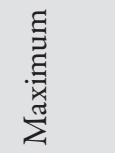 & $\underbrace{\stackrel{\Xi}{\Xi}}$ & \\
\hline April & 31 & 15.06 & 7.83 & 0.98 & 0.71 & 7.28 \\
\hline May & 31 & 21.2 & 12.56 & 0.98 & 0.65 & 3.62 \\
\hline June & 31 & 29.54 & 18.87 & 0.53 & 52.34 & 0.97 \\
\hline July & 31 & 27.32 & 19.90 & 0.96 & 0.62 & 5.55 \\
\hline August & 31 & 31.64 & 21.74 & 0.97 & 0.58 & 4.66 \\
\hline
\end{tabular}

Tab. 2. Analysis of soil tested

\begin{tabular}{cc}
\hline Characteristics & Size \\
\hline Sampling depth & $0-30 \mathrm{~cm}$ \\
pH & 6.1 \\
\hline Electrical conductivity (EC) & $138.4 \mu \mathrm{s} . \mathrm{m}$ \\
\hline Clay & $56 \%$ \\
Silt & $44 \%$ \\
\hline Sand & $10 \%$ \\
\hline Soil texture & clay \\
Nitrogen & $0.216 \%$ \\
\hline Carbon & $3.289 \%$ \\
\hline Phosphorus & 15.2 part in million \\
Potassium & 21 part in million \\
\hline Dry bulk density & 1.1 \\
\hline Particle density & 2.83 \\
Organic material & 5.666 \\
Porosity & $65.75 \%$ \\
\hline
\end{tabular}

10 days before harvesting. To improve plant growth nitrogen fertilizer from urea source was applied in the amount of $150 \mathrm{~kg}$ per hectare. It's mentionable that, two-thirds of urea was used during transplantation and one- third during tillering stage. Moreover, phosphorus fertilizer from ammonium phosphate source was used in the amount of $100 \mathrm{~kg}$ per hectare during transplantation.

Nineteen traits were evaluated to study the impacts of drough stress on the genotypes which were : plant height, panicle length, panicle number per plant, flag leaf length, flag leaf width, brown grain length, brown grain width, days up to $50 \%$ flowering, days till complete maturity, the number of filled grains in panicle, the number of spikelet per panicle, panicle fertility percentage, 1000-grains weight, yield, chlorophyll index, chlorophyll a, b and total chlorophyll and the osmotic potential. All of these measurements were done according to standard estimate system (SES) of rice.

Additionally four traites: chlorophyll $\mathrm{a}, \mathrm{b}$ and total as well as osmotic potential were measured in flowering-pollination stage (76 days after transplant). Composite sam- 
116

Tab. 3. Major specifications and features of 30 studied rice cultivars in this research

\begin{tabular}{|c|c|c|c|c|}
\hline Cultivar code & Cultivar name & Origin & Plant height & Maturity period \\
\hline 1 & 'Binam' & Iran native & Tall & Middle-maturing \\
\hline 2 & 'Champabodar' & Iran native & Tall & Late maturing \\
\hline 3 & 'Hasansaraei' & Iran native & Tall & Middle-maturing leaning to the Late Maturing \\
\hline 4 & 'Domzard' & Iran native & Tall & Middle-maturing leaning to the Late-Maturing \\
\hline 5 & 'Domsorkh' & Iran native & Tall & Middle-maturing leaning to the Late-Maturing \\
\hline 6 & 'Domsephid' & Iran native & Tall & Middle-maturing leaning to the Late-Maturing \\
\hline 7 & 'Domsiah' & Iran native & Tall & Middle-maturing leaning to the Late-Maturing \\
\hline 8 & 'Deylamani' & Iran native & Tall & Early maturing \\
\hline 9 & 'Salari' & Iran native & Tall & Middle-maturing leaning to the Late maturing \\
\hline 10 & 'Sadri' & Iran native & Tall & Middle-maturing \\
\hline 11 & 'Anbarboo' & Iran native & Tall & Late maturing \\
\hline 12 & 'Gharib' & Iran native & Tall & Middle-maturing \\
\hline 13 & 'Hashemi' & Iran native & Tall & Middle-maturing \\
\hline 14 & 'Bejar' & Iran (breeding) & Dwarf & Late maturing \\
\hline 15 & 'Khazar' & Iran (breeding) & Semi-Dwarf & Middle-maturing \\
\hline 16 & 'Dorfak' & Iran (breeding) & Dwarf & Middle-maturing \\
\hline 17 & 'Sephidroud' & Iran (breeding) & Dwarf & Middle-maturing \\
\hline 18 & 'Kadous' & Iran (breeding) & Dwarf & Middle-maturing \\
\hline 19 & 'Neda' & Iran (breeding) & Dwarf & Middle-maturing \\
\hline 20 & 'Nemat' & Iran (breeding) & Dwarf & Late-Maturing \\
\hline 21 & 'IR24' & IRRI & Dwarf & Middle-maturing leaning to the Late maturing \\
\hline 22 & 'IR28' & IRRI & Dwarf & Middle-Maturing leaning to the Late maturing \\
\hline 23 & 'IR30' & IRRI & Dwarf & Late maturing \\
\hline 24 & IR36 & IRRI & Dwarf & Middle-maturing leaning to the Late maturing \\
\hline 25 & 'IR50' & IRRI & Dwarf & Middle-maturity leaning to the Late maturing \\
\hline 26 & 'IR60' & IRRI & Dwarf & Middle-maturity leaning to the Late maturing \\
\hline 27 & 'IR64' & IRRI & Dwarf & Late maturing \\
\hline 28 & 'Araguaya' & Brezil (upland) & Semi-Dwarf & Middle-maturing \\
\hline 29 & 'New Bonnet' & USA (upland) & Dwarf & Middle-maturing \\
\hline 30 & 'Vandana' & India (uplan) & Semi-Dwarf & Early maturing \\
\hline
\end{tabular}

ples were made by combination of three times tested replication. For data analysis and the review of the difference between genotypes, analysis of variance was performed. Then cluster analysis was used. Analysis of variance and mean comparisons were performed by SAS-6.12 Software and cluster analysis was performed by SPSS-15 software.

To evaluate drought resistance at the studied cultivars, different indices were calculated through grain yield in two optimal irrigation and drought stress conditions, as follows:

1-Stress sensitivity index (SSI), proposed by Fischedr and Maurer (1978).

$$
\begin{aligned}
& S S I=\left(1-\left(Y_{P} / Y_{S}\right)\right) / S I \\
& S I=\left(1-\left(\bar{Y}_{S} / \bar{Y}_{P}\right)\right)
\end{aligned}
$$

In the above formula SI stands for stress intensity and SI is inversely related to the stress sensitivity index (SSI). In general, decrease of this index indicates less sensitivity of genotypes to stress in other word it means more resistance to drought stress.

2-Drought response index (DRI) was proposed by Bidinger et al. (1978):

$$
\begin{aligned}
& D R I=\left(Y_{A}-Y_{E S}\right) / S_{E S} \\
& D R I=\left(Y_{A}-Y_{E S}\right) / S_{E S}
\end{aligned}
$$

In which, YA depicts actual yield under stress conditions, $Y_{E S}$ depicts the prediction of yield under stress conditions through regression $S_{E S}$ depicts the standard error of multivariate regression.

In this method, a multivariate regression of grain yield under stress on grain yield and number of days to 50 percent flowering under normal condition is calculated for all genotypes and then DRI for each genotype would be calculated using:

$$
R D I=D I / \bar{X}_{D I}
$$

DRI positive values indicate the drought tolerance which is independent of the impacts of potential yield and 
flowering date. DRI is proportioned to SI-1 (stress intensity minus 1) in Fischedr and Maurer formula (1978).

3-Relative drought index (RDI) was presented by the Fischedr and Maurer (1978):

$$
\begin{aligned}
& D I=Y_{S} / Y_{P} \\
& \bar{X}_{D I}=\bar{Y}_{S} / \bar{Y}_{P}
\end{aligned}
$$

In this regard, DI depicts drought index which is calculated according to the ratio of grain yield in each cultivar under stress conditions to normal. $\bar{X}$ depicts the average of drought index which is calculated according to the ratio of yield average of all studied cultivars under stress conditions to yield average of all cultivars under optimal conditions.

If RDI is greater than one, it means the genotypes will have relative tolerance to drought and If RDI is smaller than one, it means genotypes will have relative sensitive to drought (Fischedr and Maurer (1978).

Tolerance index (TOL) is represented by yield difference between a genotype in stress and nonstress environments. And Arithmetic mean index (MP) or Middle Product index is represented using the yield mean of genotype in two environments.

4-Tolerance index (TOL) was proposed by Rosielle and Hamblin (1981) and it's calculated via difference between grain yield of each cultivar under optimal irrigation conditions (YP) and drought stress (YS). If the difference between the YP and YS increased, the amount of TOL would increase and this represents that the cultivar is more sensitive to drought.

$$
T O L=Y_{P}-Y_{S}
$$

5-Arithmetic mean index (MP), which is the grain yield average of each cultivar under optimal and stress conditions. MP index was proposed by Rosielle and Hamblin (1981):

$$
M P=\left(Y_{P}+Y_{S}\right) / 2
$$

6-Stress tolerance index (STI) is represented by Fernandes (1992). In contrast to tolerance index (TOL), where STI increases it shows that genotype has a higher tolerance to drought.

$$
S T I=\left(Y_{P}\right)\left(Y_{S}\right) /\left(\bar{Y}_{P}\right)^{2}
$$

In contrast to tolerance index (TOL), where STI increase shows that genotype has a higher tolerance to drought.

7-Geometric mean index (GMP) was introduced by Fernandes (1992):

$$
G M P=\sqrt{\left(Y_{P}\right)\left(Y_{S}\right)}
$$
lows:

8-Harmonic mean index (HM) is calculated as fol-

$$
H M=2\left(Y_{P}\right)\left(Y_{S}\right) /\left(Y_{P}+Y_{S}\right)
$$

\section{Results and discussion}

The results showed that, there were significant effects among genotypes considering all the studied traits $(\mathrm{p}$ $<0.01$ ) (Tab. 4). Thus significant differences among genotypes high genetic diversity can be shown among the studied population, regarding the evaluated traits.

Results through the mean comparisons (Tab. 5) showed that, the highest and the lowest plant height were related to 'Champabodar' (172.25 cm) and 'IR24' (74.80 $\mathrm{cm}$ ), respectively. Among cultivars, 'Nemat' and 'Araguaya' with a mean of 35.20 and $22.30 \mathrm{~cm}$ had the highest and lowest panicle length, respectively. 'Hasansaraei' had the highest mean $(41.92 \mathrm{~cm})$ while 'IR60' had the lowest one $(22.68 \mathrm{~cm})$ considering flag leaf length. The 'Champabodar' had the maximum mean of flag leaf width (2.18) while 'Domsephid' had the minimum mean $(1.12 \mathrm{~cm})$. The results demonstrated that, the highest and the shortest brown grain length was observed in 'Nemat' cultivar $(8.67 \mathrm{~mm})$ and 'Champabodar' $(6.03 \mathrm{~mm})$, respectively. Cultivars with the highest brown grain length had better appearance, economic and commercial values, because rice consumers generally prefer long seeds. After cooking, usually these cultivars create long grain, completely separated from each other. So, 'Kadous', 'Dorfak', 'Neda' and 'Nemat' cultivars have better appearance while 'Champabodar', 'IR60' and the 'New Bonnet' own the lowest value. A comparison on the brown grain width showed that, 'Gharib' and 'Domsephid' had the highest $(1.84 \mathrm{~mm})$ and the lowest $(1.33 \mathrm{~mm})$ amount, respectively. Cultivars with more grain length and less grain width have better qualitative appearance and thus consumers will prefer them. 'Domsephid' (91.33 days) and 'IR36' cultivars (75.66 days) were the latest-and the earliest-matured cultivars, respectively. At the beginning of tillering stage, drought stress decreased number of days up to $50 \%$ flowering. Under conditions of drought stress, cultivars with earlier reproductive stage can be more tolerant at the end of season and they produce more yields because premature flowering is an important characteristic to overcoming drought stress. Jongdee et al. (2006) have been reported that, in severe drought stress conditions, early flowering feature was a very important mechanism to escape from drought stress. Therefore, differences in flowering time among genotypes under these conditions can be used as stress tolerance index. Lafitte et al. (2003) also expressed that selection based on time of flowering, which does not occurre at the same time with water deficit period, will be very effective method for drought tolerance improval. Similar to this citation, Richards (1996) expressed that, phenological traits are the most important characteristics in connection with improved drought resistance. The study on maturity period showed that, 'IR24' (111.66 days) and 'Bejar' (96.66 days) were the latest-matured and the earliest-matured cultivars, respectively. The results of days to $50 \%$ flowering trait can be generalized to this trait. Fukai (1999) also showed that 
118

yield stability and high yield of rice grown under drought stress could prevent from flowering synchrony and maturation with late drought stress. Therefore in this sort of researchs, its necessity to pay attention to prematuring trait for minimizeing the impacts of stress in the flowering period, because flowering period is the main stage to determine grain yield and yield components of rice.

Some data such as days to $50 \%$ flowering and days to full maturity was obtained due to some problems on 6 June 2007. Transplanting with delay decresed plant growth period and then the plants were early matured in comparison with those plants which were transplanted at suitable time. Referring to the number of filled grains in panicle, 'Nemat' (193.33) had the highest mean and 'Domsephid' cultivar (92) had the lowest. Therefor probably cultivars as 'Nemat', 'Sephidroud', 'Bejar,' 'Champabodar' and 'IR64' are more able to transmit assimilates to the seed and finally produce more filled seeds. In contrast, 'Domsorkh', 'Domsephid', 'Khazar' and 'IR36' were weak in respect of assimilate transfer into the seeds under drought stress and produced further hollow seeds. The results showed that, 'Nemat' had the maximum (211.33) and 'New Bonnet' (67.6) had the minimum seed number per panicle. In regard of panicle fertility percentage, 'Nemat' cultivar and 'New Bonnet' cultivar had the highest (91.48\%) and the lowest (67.6\%) fertility percentage, respectively. A measurement of 1000 seeds weight demonstrated that, 'Nemat' cultivar with mean of $35.08 \mathrm{~g}$ and 'Domsephid' cultivar with mean of $23.97 \mathrm{~g}$ had the highest and lowest 1000-grains weight, respectively.

Comparisons of mean on seed yield showed that, 'Nemat' cultivar and 'Domsephid' cultivar had the highest $\left(5126.6 \mathrm{~kg} / \mathrm{ha}^{-1}\right)$ and the lowest $\left(1565.9 \mathrm{~kg} / \mathrm{ha}^{-1}\right)$ seed yield, respectively. Increase or decrease of this trait can be due to variety of yield components and different response to environmental conditions. Water stress at the end of vegetative stage and flowering stage, especially pollination stage reduces seed filling and then decreases seed yield. Also, decrease in 1000-grains weight and even the number of fertile panicle per plant are other reasons for the reduction of yield under drought stress conditions (Guolan et al., 2010). Fukai and Cooper (1995) have stated that, physiological researches and breeding programs at the same time can help recognize drought resistant genotypes according to their yield. Accordingly, drought resistant genotypes have a higher yield than the other ones. Therefore, considering the high yield in 'Nemat' cultivar and having suitable flowering time, this cultivar will be selected as suitable cultivar for planting under drought conditions. In addition, under full stress conditions, selection of cultivars based on yield isn't enough, since grain yield is a quantitative trait, controlled by a large number of genes.

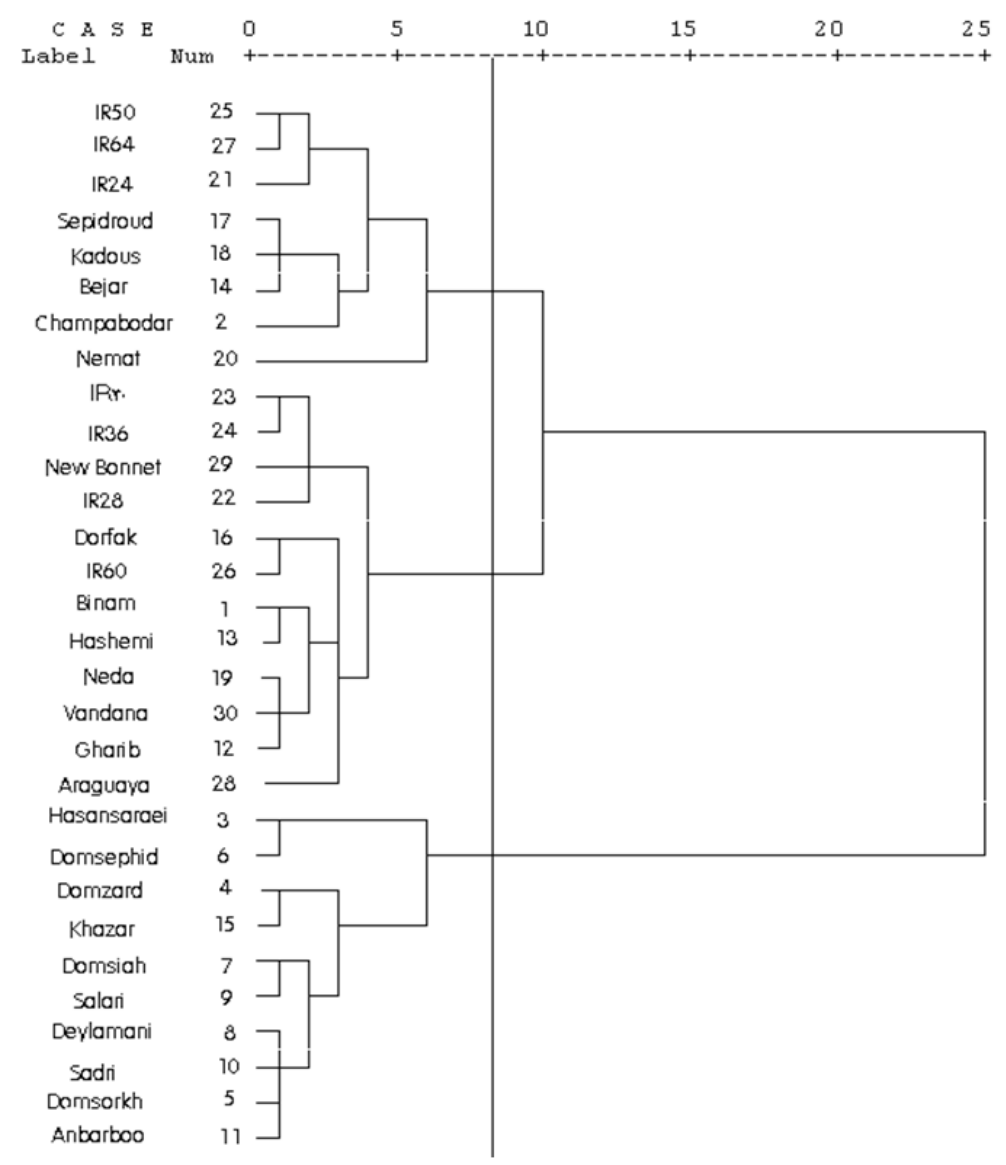

Fig. 1. Cluster analysis dendrogram of 30 studied rice cultivars according to all measured traits in drought stress conditions 
Tab. 4. Analysis of variance on different rice traits under drought stress conditions

\begin{tabular}{|c|c|c|c|c|c|c|c|c|c|c|c|c|c|c|c|}
\hline & & $\begin{array}{l}\text { Plant } \\
\text { height }\end{array}$ & $\begin{array}{c}\text { Panicle } \\
\text { lenth }\end{array}$ & $\begin{array}{c}\text { Panicle } \\
\text { number } \\
\text { per plant }\end{array}$ & $\begin{array}{c}\text { Flag leaf } \\
\text { lenght }\end{array}$ & $\begin{array}{l}\text { Flag leaf } \\
\text { width }\end{array}$ & $\begin{array}{l}\text { Brown grain } \\
\text { length }\end{array}$ & $\begin{array}{c}\text { Brown grain } \\
\text { width }\end{array}$ & $\begin{array}{c}\text { Days } \\
\text { to } 50 \% \\
\text { flowering }\end{array}$ & $\begin{array}{l}\text { Days to } \\
\text { complete } \\
\text { maturity }\end{array}$ & $\begin{array}{l}\text { The number } \\
\text { of filled grains } \\
\text { in panicle }\end{array}$ & $\begin{array}{c}\text { The } \\
\text { number of } \\
\text { spikelet per } \\
\text { panicle }\end{array}$ & $\begin{array}{c}\text { Panicle } \\
\text { fertility } \\
\text { percentage }\end{array}$ & $\begin{array}{c}\text { 1000-grain } \\
\text { weight }\end{array}$ & Yield \\
\hline Block & 2 & $0.96^{\mathrm{ns}}$ & $0.63^{\text {ns }}$ & $1.51^{\mathrm{ns}}$ & $4.65^{\mathrm{ns}}$ & $0.34^{\prime \prime}$ & $0.02^{\mathrm{ns}}$ & $0.0003^{\mathrm{ns}}$ & $3.24^{\mathrm{ns}}$ & $15.01^{\mathrm{ns}}$ & $6.21^{\mathrm{ns}}$ & $1.47^{\mathrm{ns}}$ & $1.65^{\mathrm{ns}}$ & 35.6 & \\
\hline Geotype & 29 & $3094.49^{\circ}$ & $33.008^{\prime \prime}$ & $50.55^{\prime \prime}$ & $49.23^{\prime \prime}$ & $0.18^{\prime \prime}$ & $1.33^{\prime \prime}$ & $0.003^{*}$ & $40.36^{\prime \prime}$ & $75.5^{\prime \prime}$ & $1136.56^{\circ}$ & $1115.73^{\prime \prime}$ & $51.29^{*}$ & $21.85^{\prime \prime}$ & $2035926.49 "$ \\
\hline Error & 58 & 1.5 & 0.3 & 0.73 & 3.5 & 0.03 & 0.01 & 0.0004 & 5.92 & 14.22 & 3.03 & 2.05 & 1.95 & 4.98 & 250918.88 \\
\hline CV $(\%$ & & 1.33 & 1.94 & 5.16 & 6.11 & 11.23 & 1.61 & 1.25 & 2.92 & 3.61 & 1.5 & 0.97 & 1.78 & 7.4 & 16.7 \\
\hline
\end{tabular}

$\mathrm{ns}^{*}{ }^{*}$ and ${ }^{* *}$, no significant, significant at 0.05 and significant at 0.01 probability level, respectively. Chlorophyll index is: SPAD value in 76 days after transplantation (stages of flowering and pollination)

Tab. 6. Mean, standard error of measurement and mean deviation of groups resulted from cluster analysis from total mean of 30-studied rice cultivars traits in drought stress conditions

\begin{tabular}{|c|c|c|c|c|c|c|c|c|c|}
\hline \multicolumn{10}{|c|}{ Standard Error $( \pm)$ Mean } \\
\hline & $\begin{array}{l}\text { Plant height } \\
(\mathrm{cm})\end{array}$ & $\begin{array}{l}\text { Panicle lenth } \\
(\mathrm{cm})\end{array}$ & $\begin{array}{c}\text { Panicle number } \\
\text { per plant }\end{array}$ & $\begin{array}{l}\text { Flag leaf lenght } \\
(\mathrm{cm})\end{array}$ & $\begin{array}{l}\text { Flag leaf } \\
\text { width }(\mathrm{cm})\end{array}$ & $\begin{array}{l}\text { Brown grain } \\
\text { length }(\mathrm{mm})\end{array}$ & $\begin{array}{l}\text { Brown grain } \\
\text { width }(\mathrm{mm})\end{array}$ & $\begin{array}{c}\text { Days to } 50 \% \\
\text { flowering }\end{array}$ & $\begin{array}{l}\text { Days to complete } \\
\text { maturity }\end{array}$ \\
\hline Group 1 & $99.52 \pm 30.63$ & $31.95 \pm 2.91$ & $22.01 \pm 3.38$ & $32.16 \pm 3.51$ & $1.75 \pm 0.24$ & $7.35 \pm 0.75$ & $1.73 \pm 0.05$ & $81.75 \pm 2.82$ & $105.04 \pm 5.84$ \\
\hline Group mean deviation from total mean & -18.77 & 3.52 & 5.35 & 1.52 & 0.22 & 0.29 & 0.06 & -1.32 & 0.83 \\
\hline Group 2 & $106.89 \pm 27.14$ & $27.33 \pm 2.72$ & $15.53 \pm 2.23$ & $30.30 \pm 2.95$ & $1.54 \pm 0.12$ & $6.93 \pm 0.71$ & $1.69 \pm 0.06$ & $82.05 \pm 3.14$ & $102.77 \pm 4.66$ \\
\hline Group mean deviation from total mean & -11.4 & -1.08 & -1.12 & -0.32 & 0.008 & -0.13 & 0.02 & -1.02 & -1.43 \\
\hline Group 3 & $147.01 \pm 17.05$ & $26.9 \pm 2.14$ & $13.72 \pm 1.57$ & $29.8 \pm 5.44$ & $1.35 \pm 0.21$ & $6.98 \pm 0.51$ & $1.58 \pm 0.11$ & $85.36 \pm 4.03$ & $105.26 \pm 4.82$ \\
\hline Group mean deviation from total mean & 28.7 & -1.51 & -2.93 & -0.83 & -0.18 & -0.07 & -0.08 & 2.28 & 1.05 \\
\hline Total Mean & 118.3 & 28.42 & 16.65 & 30.63 & 1.53 & 7.06 & 1.66 & 83.07 & 104.21 \\
\hline
\end{tabular}

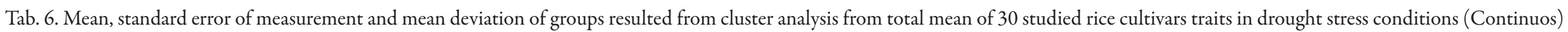

\begin{tabular}{|c|c|c|c|c|c|c|c|c|c|c|}
\hline \multicolumn{11}{|c|}{ Standard Error $( \pm)$ Mean } \\
\hline & $\begin{array}{l}\text { The number of filled } \\
\text { grains in panicle }\end{array}$ & $\begin{array}{c}\text { The number of } \\
\text { spikelet per panicle }\end{array}$ & $\begin{array}{c}\text { Panicle fertility } \\
\text { percentage }\end{array}$ & $\begin{array}{c}\text { 1000-grains } \\
\text { weight }\end{array}$ & Yield (kg.ha) & $\begin{array}{l}\text { Chlorophyll } \\
\text { index }\end{array}$ & $\begin{array}{l}\text { Chlorophyll } \\
\text { a (mg.g) }\end{array}$ & $\begin{array}{l}\text { Chlorophyll } \\
\text { b (mg.g) }\end{array}$ & $\begin{array}{l}\text { Total chlorophyll } \\
\text { (mg.g) }\end{array}$ & $\begin{array}{c}\text { Osmotic } \\
\text { potensial (bar) }\end{array}$ \\
\hline Group 1 & $136.5 \pm 23.11$ & $169.58 \pm 18.27$ & $80.17 \pm 5.11$ & $32.39 \pm 1.95$ & $3724.11 \pm 883.74$ & $36.53 \pm 2.52$ & $0.85 \pm 0.1$ & $0.62 \pm 0.04$ & $1.93 \pm 0.15$ & $-8.18 \pm 0.7$ \\
\hline Group mean deviation from total mean & 20.64 & 22.06 & 1.85 & 2.23 & 726.29 & -0.06 & 0.03 & 0.007 & 0.006 & -0.75 \\
\hline Group 2 & $113.38 \pm 10.85$ & $143.44 \pm 11.96$ & $79.06 \pm 4.27$ & $30.52 \pm 2.23$ & $3006.24 \pm 488.25$ & $38.32 \pm 2.06$ & $0.94 \pm 0.09$ & $0.68 \pm 0.04$ & $2.18 \pm 0.19$ & $-8.23 \pm 0.52$ \\
\hline Group mean deviation from total mean & -2.46 & -4.07 & 0.74 & 0.36 & 8.42 & 1.72 & 0.11 & 0.06 & 0.26 & -0.17 \\
\hline Group 3 & $102.3 \pm 8.35$ & $134.76 \pm 11.66$ & $75.95 \pm 1.55$ & $27.94 \pm 2.06$ & $2406.66 \pm 656.24$ & $34.57 \pm 1.11$ & $0.65 \pm 0.08$ & $0.52 \pm 0.04$ & $1.6 \pm 0.18$ & $-7.25 \pm 0.51$ \\
\hline Group mean deviation from total mean & -13.55 & -12.75 & -2.37 & -2.22 & -591.14 & -2.02 & -0.16 & -0.08 & -0.31 & 0.8 \\
\hline Total Mean & 115.85 & 147.52 & 78.32 & 30.16 & 2997.81 & 36.59 & 0.82 & 0.61 & 1.92 & -8.05 \\
\hline
\end{tabular}

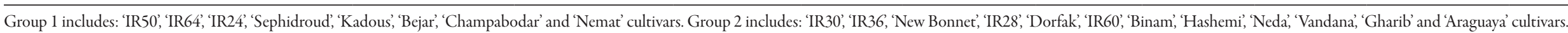

Group 3 includes:'Hasansaraei,' 'Domsephid,' 'Domzard,' 'Khazar,' 'Domsiah,', 'Salari,', 'Deylamani,', 'Sadri', 'Domsorkh' and 'Anbarboo' cultivars 
120

Tab. 5. Mean comparison of rice genotype considering studied traits by Tukey (HSD) and LSD method

\begin{tabular}{|c|c|c|c|c|c|c|c|c|c|c|c|c|c|c|c|}
\hline Cultivar & $\begin{array}{l}\text { Plant } \\
\text { height } \\
(\mathrm{cm})\end{array}$ & $\begin{array}{l}\text { Panicle } \\
\text { lenth } \\
(\mathrm{cm})\end{array}$ & $\begin{array}{l}\text { Panicle } \\
\text { number } \\
\text { per plant }\end{array}$ & $\begin{array}{l}\text { Flag leaf } \\
\text { length } \\
(\mathrm{cm})\end{array}$ & $\begin{array}{l}\text { Flag leaf } \\
\text { width } \\
(\mathrm{cm})\end{array}$ & $\begin{array}{l}\text { Brown grain } \\
\text { length }(\mathrm{mm})\end{array}$ & $\begin{array}{l}\text { Brown grain } \\
\text { width }(\mathrm{mm})\end{array}$ & $\begin{array}{c}\text { Days } \\
\text { to } 50 \% \\
\text { flowering } \\
\end{array}$ & $\begin{array}{l}\text { Days to } \\
\text { complete } \\
\text { maturity }\end{array}$ & $\begin{array}{l}\text { The number } \\
\text { of filled grains } \\
\text { in panicle }\end{array}$ & $\begin{array}{c}\text { The number } \\
\text { of spikelet } \\
\text { per panicle }\end{array}$ & $\begin{array}{c}\text { Panicle } \\
\text { fertility } \\
\text { percentage }\end{array}$ & $\begin{array}{c}\text { 1000-grains } \\
\text { weight }\end{array}$ & $\begin{array}{l}\text { Yield (kg. } \\
\left.\mathrm{ha}^{-1}\right)\end{array}$ & $\begin{array}{l}\text { Chlorophyll } \\
\text { index }\end{array}$ \\
\hline 'Binam' & 153.6 & 30.76 & 18.63 & 29.3 & 1.52 & 6.89 & 1.67 & 81.66 & 112.33 & 100.33 & 153.33 & 80.65 & 28.17 & 2730.36 & 35.8 \\
\hline 'Champabodar' & 172.25 & 33.53 & 18.41 & 33.22 & 2.18 & 6.03 & 1.83 & 86.66 & 102.33 & 107.66 & 167.33 & 77.68 & 33.38 & 3360.14 & 36.9 \\
\hline 'Hasansaraei' & 169.25 & 25.63 & 13.9 & 41.92 & 1.25 & 6.07 & 1.52 & 90.66 & 97 & 112.33 & 134.66 & 77.72 & 27.20 & 2053.41 & 34.6 \\
\hline 'Domzard' & 149.33 & 27.08 & 16.86 & 31.87 & 1.66 & 6.67 & 1.52 & 79 & 102 & 102 & 136.66 & 78.05 & 29.55 & 3351.6 & 34.43 \\
\hline 'Domsorkh' & 139.38 & 30.94 & 11.53 & 25.5 & 1.21 & 7.46 & 1.63 & 86 & 103.66 & 107.33 & 123.66 & 76.84 & 27.47 & 2109.66 & 35.26 \\
\hline 'Domsephid' & 171.7 & 30.4 & 12.8 & 36.41 & 1.12 & 6.96 & 1.33 & 91.33 & 111.33 & 111.33 & 121.66 & 75.61 & 23.97 & 1565.89 & 32.33 \\
\hline 'Domsiah' & 132.08 & 25.66 & 13.8 & 28.78 & 1.38 & 7.45 & 1.64 & 85.66 & 97 & 102.33 & 163 & 74.45 & 30.15 & 2517.74 & 43.9 \\
\hline 'Deylamani' & 158.48 & 24.76 & 14.3 & 25.3 & 1.14 & 6.95 & 1.63 & 82.33 & 102 & 102 & 129.33 & 75.77 & 27.42 & 1929.22 & 35.4 \\
\hline 'Salari' & 147.47 & 26.8 & 13.73 & 27.62 & 1.34 & 7.44 & 1.57 & 88.33 & 98 & 98 & 140.66 & 74.4 & 29.85 & 2297.46 & 34.23 \\
\hline 'Sadri' & 139.18 & 25.13 & 15.06 & 26.36 & 1.26 & 7.34 & 1.71 & 84 & 101.33 & 101.33 & 128.66 & 77.2 & 30.58 & 2147.36 & 35.76 \\
\hline 'Anbarboo' & 148.12 & 27.13 & 13.6 & 27.63 & 1.34 & 6.22 & 1.72 & 85.66 & 109.66 & 109.66 & 138.33 & 76.14 & 26.64 & 2367.75 & 35.7 \\
\hline 'Gharib' & 146.89 & 28.03 & 12.63 & 30.16 & 1.59 & 6.21 & 1.84 & 82.66 & 102 & 102 & 145.66 & 80.09 & 33.84 & 3265.29 & 40.23 \\
\hline 'Hashemi' & 132.23 & 28.1 & 16.53 & 30.08 & 1.49 & 8.009 & 1.66 & 79 & 102.66 & 99 & 144.66 & 80.18 & 32.43 & 2700.36 & 39.06 \\
\hline 'Bejar' & 100.96 & 32.94 & 21.86 & 28.48 & 1.7 & 7.45 & 1.76 & 80.66 & 104 & 96.66 & 162 & 80.45 & 35.08 & 3810.45 & 36.2 \\
\hline 'Khazar' & 114.88 & 25.53 & 11.53 & 26.58 & 1.78 & 7.29 & 1.49 & 80.66 & 106.33 & 106.33 & 131 & 73.28 & 26.55 & 3726.55 & 33.13 \\
\hline 'Dorfak' & 102.7 & 30.86 & 15 & 30.31 & 1.54 & 8.13 & 1.75 & 83.66 & 104.66 & 104.66 & 135.66 & 84.52 & 32.53 & 2847.92 & 39.53 \\
\hline 'Sephidroud' & 89.62 & 34.3 & 24.2 & 35.24 & 1.91 & 7.35 & 1.76 & 77.33 & 102 & 102 & 171 & 76.81 & 30.41 & 4830.47 & 38.26 \\
\hline 'Kadous' & 94.3 & 33.73 & 18.63 & 33.9 & 1.8 & 7.77 & 1.72 & 81.66 & 103 & 103 & 165 & 76.97 & 32.6 & 3702.09 & 41.13 \\
\hline 'Neda' & 94.53 & 26.92 & 18.4 & 31.55 & 1.68 & 7.59 & 1.71 & 86 & 104.33 & 104.33 & 152.66 & 82.31 & 33.91 & 3424.02 & 37.36 \\
\hline 'Nemat' & 98.34 & 35.2 & 28.2 & 37.4 & 1.9 & 8.67 & 1.69 & 80 & 95.33 & 104 & 211.33 & 91.48 & 35.08 & 5126.62 & 37.56 \\
\hline 'IR24' & 76.26 & 30.26 & 18.83 & 27.22 & 1.36 & 6.79 & 1.69 & 83 & 115.66 & 116.66 & 148.33 & 82.7 & 31.11 & 2415.61 & 33.6 \\
\hline 'IR28' & 74.8 & 28.7 & 17.03 & 34.77 & 1.7 & 6.13 & 1.66 & 80 & 98 & 98 & 147.66 & 81.03 & 29.19 & 3958.002 & 42.93 \\
\hline 'IR30' & 87.04 & 25.2 & 15.13 & 29.1 & 1.42 & 6.04 & 1.65 & 82.33 & 107.33 & 100 & 130 & 76.41 & 27.11 & 2588.27 & 39.36 \\
\hline 'IR36 & 83.9 & 29.16 & 15.66 & 28.82 & 1.52 & 6.77 & 1.57 & 75.66 & 99.66 & 99.66 & 125 & 76.8 & 28.59 & 282952 & 36.33 \\
\hline 'IR50' & 79.66 & 27.76 & 23.5 & 29.44 & 1.56 & 7.44 & 1.66 & 84 & 107.66 & 102.66 & 169.66 & 75.64 & 31.15 & 3179.72 & 34.76 \\
\hline 'IR60' & 78.57 & 28.96 & 17.96 & 22.68 & 1.31 & 6.94 & 1.72 & 84.66 & 104.66 & 104.66 & 148.66 & 81.16 & 30.43 & 2295.87 & 38.8 \\
\hline 'IR64' & 84.83 & 27.9 & 22.5 & 32.37 & 1.64 & 7.28 & 1.7 & 80.66 & 107.66 & 107.66 & 162 & 79.62 & 30.36 & 3367.76 & 33.83 \\
\hline 'Araguaya' & 119.63 & 22.3 & 12.3 & 32.39 & 1.66 & 7.08 & 1.71 & 87 & 116.66 & 115.66 & 125 & 77.61 & 29.71 & 3396.52 & 36.36 \\
\hline 'New Bonnet' & 91.96 & 23.44 & 12.86 & 31.96 & 1.4 & 7.14 & 1.63 & 80 & 96 & 103.66 & 158.33 & 67.6 & 29.34 & 2562.82 & 37.33 \\
\hline 'Vandana' & 119.82 & 25.6 & 14.23 & 32.5 & 1.68 & 6.2 & 1.66 & 82 & 101.33 & 101.33 & 154.66 & 80.38 & 30.98 & 3475.91 & 36.76 \\
\hline $\mathrm{HSD}_{0.05}$ & 3.95 & 1.78 & 2.76 & 6.02 & 0.56 & 0.36 & 0.06 & 7.83 & 12.14 & 5.61 & 4.61 & 4.49 & 7.18 & 1612.5 & 9.21 \\
\hline $\mathrm{LSD}_{0,05}$ & 2.007 & 0.9 & 1.4 & 3.06 & 0.28 & 0.18 & 0.03 & 3.97 & 6.16 & 2.84 & 2.34 & 2.28 & 3.65 & 818.7 & 4.67 \\
\hline
\end{tabular}

HSD (Tukey's Studentized Range) with Alpha $=0.05$ : LSD (Least Significant Difference) with $\alpha=0.05$ 
The results of mean comparisions of the chlorophyll index (76 days after transplantation and in flowering-pollination stage) showed that, 'IR24' and 'Domsephid' had the highest (42.93) and lowest (32.33) value, respectively.

To have idea about the extent of similarity and differences among the studied rice cultivars under drought stress, cluster analysis of genotypes was performed based on all of traits and tolerance to drought using Ward minimum variance method. Then, groups were compared. Cluster analysis, based on all the studied traits, devided genotypes into three groups (Fig. 1).

In the first group there were reformed cultivars such as 7 of breeding ones with a local cultivar ('Champabodar'). This group had the highest average in comparison with the other two groups considering many traits such as panicle length (31.95), panicle number per plant (22.01), flag leaf length (32.16), flag leaf width (1.75), brown grain length (7.35), brown grain width (1.73), the number of filled grains in panicles (136.5), the number of spikelet per panicle (169.58), panicle fertility percentage (80.17), 1000-grains weight (32.39) and yield (3724.11). Considering traits such as plant height (99.53), days up to $50 \%$ of flowering (81.75) and the osmotic potential (-8.81) this group had the lowest average in three groups (Tab. 5).

The second group consists of 12 cultivars. There were all three upland cultivars with a number of native and breeding cultivars in this group (Fig. 1). In respect of physiological traits such as chlorophyll index (38.32), chlorophyll a (0.94), chlorophyll b (0.68) and total chlorophyll content (2.18) this group had the highest average among all groups and with regard to two traits: brown grain lenght (6.93) and days to complete maturity (102.77) it had the lowest average (Tab. 6).

The third group included 10 cultivars; all of them were Irannian local cultivars except 'Khazar' breeding cultivar. In contrast to the first group, this one had the minimum value regarding many of the traits, so that genotypes of this group had the lowest average for traits such as, panicle length (26.9), number of panicle per plant (13.72), flag leaf length (29.8), flag leaf width (1.35), brown grain width (1.58), number of filled grains in panicle (102.3), number of clusters per panicle (134.76) panicle fertility percentage (75.95), 1000-grains weight (27.94), yield (2406.66), chlorophyll index (34.57), chlorophyll a (0.65), chlorophyll $\mathrm{b}(0.52)$ and total chlorophyll (1.60) and it had the highest average only for four traits such as, plant height (147.01), days up to $50 \%$ of flowering (85.36), days to complete maturity (105.26) and the osmosis potential $(-7.25)$ (Tab. 6)

The results of cluster analysis and deviation from the averages showed that, there was the highest difference cosidering most of the traits, especially about yield and yield components under drought stress conditions, between the first and the third cluster. Thus, we can select some rep- resentative of each group and hybridize between them which cause the maximum genetic diversity and increase the choice of desirable genotypes under drought stress. Also it can improve some traits which are related to yield, such as the number of panicle per plant, number of filled grains in panicle; number of drough per panicle, flag leaf length and flag leaf width, so final yield can be increased under conditions of drought stress. Comparison among cultivars in these three groups shows that, if we hybridize 'Nemat', a breeded cultivar from the first group, (it had the highest average for most of studied traits under stress conditions) with 'Domsephid', a local cultivar from third group (it had the lowest average for most of studied traits) and then select resulted genotypes in generation being scattered in this hybridization, we will find lines with high tolerance to drought stress conditions and we can produce the highest yield.

In order to evaluate the sensitivity and tolerance of studied rice cultivars to drought stress, drought indices were calculated. Cultivars sush as 'Nemat', 'Sephidroud', 'IR24,' 'Kadous' and 'Bejar' had the highest values in four indices, namely: STI, GMP, MP and HM.

By comparing arithmetical mean (MP), geometric mean (GMP) and stress tolerance index (STI), genotypes were determined; selection based on these criteria can cause genotypes selection with high yield in both conditions. Other researchers also have reported this result for these indices (Quizenberry, 1982). Also cultivars such as 'Nemat', 'Sephidroud', 'IR24', 'Kadous' and 'Bejar' were positive for DRI index and values greater than one for RDI index. The lowest amount of stress sensitivity index (SSI) belonging to 'New Bonnet' cultivar, also 'Sephidroud' cultivar had relatively lower amount for the SSI index.

Evaluation of tolerance index (TOL) of studied genotypes showed that, genotypes with good tolerance to drought stress didn't have high potential yield. 'Vandana' (upland cultivar) had the lowest drought tolerance index (TOL) and it showed the greatest number of drought response index (DRI) after 'Nemat' and 'Sephidroud' cultivars and it produced desirable yield under drought stress conditions. In addition, 'Vandana' had the lowest amount of stress sensitivity index (SSI) (Tab. 7). So we can introduce these cultivars as drought resistant ones as all of them, except 'Vandana' (upland cultivar), are breeded cultivars. Cultivars of 'Domsephid', 'Deylamani', 'Hasansaraei', 'Domsiah', 'Sadri' and 'Anbarboo' had the lowest amount for four indices of STI, GMP, MP and HM and they had negative values for DRI index and cultivars of 'Deylamani' and 'Sadri' had values smaller than one for RDI index. In addition, 'Deylamani' cultivar had high values for SSI and TOL indices. Therefore cultivars of 'Domsephid', 'Deylamani', 'Hasansaraei', 'Domsiah', 'Sadri' and 'Anbarboo' are Guilan native and they can be introduced as sensitive genotypes to drought stress (Tab. 7). 
122

Tab. 7. Assessed drought resistance indexes in studied rice cultivars

\begin{tabular}{|c|c|c|c|c|c|c|c|c|}
\hline Cultivar & SSI & TOL & MP & STI & GMP & $\mathrm{HM}$ & RDI & DRI \\
\hline 'Binam' & -2.83 & 2933.44 & 4196.59 & 0.66 & 3917.1 & 3659.97 & 0.79 & -0.33 \\
\hline 'Champabodar' & -1.09 & 911.54 & 3815.91 & 0.58 & 3675.07 & 3545.92 & 1.42 & 0.85 \\
\hline 'Hasansaraei' & -1.49 & 1157.38 & 2632.1 & 0.28 & 2563.68 & 2497.36 & 1.04 & -0.54 \\
\hline 'Domzard' & -0.68 & 880.65 & 3791.93 & 0.6 & 3510.05 & 3253.69 & 2.07 & 0.53 \\
\hline 'Domsorkh' & -2.39 & 1914.25 & 3066.78 & 0.36 & 2913.38 & 2767.69 & 0.84 & -0.93 \\
\hline 'Domsephid' & -1.02 & 528.89 & 1830.34 & 0.13 & 1795.06 & 1761.06 & 1.24 & -0.86 \\
\hline 'Domsiah' & -0.82 & 704.34 & 2869.91 & 0.35 & 2830.03 & 2791.63 & 1.29 & -0.21 \\
\hline 'Deylamani' & -3.34 & 2356.75 & 3107.6 & 0.35 & 2865.46 & 2645.17 & 0.73 & -1.17 \\
\hline 'Salari' & -1.84 & 1576.5 & 3085.71 & 0.38 & 2979.7 & 2877.8 & 0.95 & -0.21 \\
\hline 'Sadri' & -2.1 & 1679.19 & 2986.96 & 0.35 & 2857.47 & 2734.72 & 0.91 & -0.59 \\
\hline 'Anbarboo' & -1.21 & 1100.31 & 2917.91 & 0.35 & 2862.33 & 2807.99 & 1.11 & -0.06 \\
\hline 'Gharib' & -1.34 & 1663.36 & 4096.97 & 0.69 & 4011.32 & 3927.5 & 1.06 & 0.27 \\
\hline 'Hashemi' & -1.36 & 1362.29 & 3381.51 & 0.47 & 3309.16 & 3238.58 & 1.06 & 0.06 \\
\hline 'Bejar' & -0.87 & 1240.1 & 4430.51 & 0.82 & 4384.94 & 4339.92 & 1.21 & 0.72 \\
\hline 'Khazar' & -1.27 & 1488.71 & 4470.91 & 0.83 & 4378.93 & 4291.65 & 1.15 & 0.64 \\
\hline 'Dorfak' & -2.13 & 2294.16 & 3995.007 & 0.62 & 3826.15 & 3664.53 & 0.89 & -0.31 \\
\hline 'Sephidroud' & -0.88 & 1556.47 & 5608.71 & 1.31 & 5537.56 & 5468.11 & 1.23 & 1.18 \\
\hline 'Kadous' & -1.54 & 2143.19 & 4773.68 & 0.92 & 4646.63 & 4523.55 & 1.02 & 0.36 \\
\hline 'Neda' & -1.74 & 2208.88 & 4528.46 & 0.82 & 4367.32 & 4214.06 & 1.01 & 0.31 \\
\hline 'Nemat' & -1.26 & 2303.75 & 6278.5 & 1.62 & 6153.17 & 6031.31 & 1.11 & 1.79 \\
\hline 'IR24' & -2.22 & 2006.28 & 3418.75 & 0.45 & 3265.83 & 3120.17 & 0.87 & -0.7 \\
\hline 'IR28' & -1.58 & 2192.01 & 5054.009 & 1.04 & 4914.14 & 478.45 & 1.04 & 0.29 \\
\hline 'IR30' & -3.71 & 3452.44 & 4314.49 & 0.66 & 3934.57 & 3593.59 & 0.69 & -0.95 \\
\hline IR36' & -1.23 & 1328.6 & 3493.82 & 0.5 & 3426.17 & 3360.15 & 1.1 & -0.19 \\
\hline 'IR50' & -2.38 & 2752.14 & 4555.79 & 0.8 & 4330.16 & 4118.33 & 0.86 & -0.1 \\
\hline 'IR60' & -3.67 & 3074.23 & 3832.99 & 0.53 & 3506.41 & 3209.23 & 0.68 & -1.08 \\
\hline 'IR64' & -1.96 & 2131.46 & 4433.5 & 0.8 & 4270.99 & 4117.79 & 0.97 & 0.04 \\
\hline 'Araguaya' & -1.4 & 1759.23 & 4276.14 & 0.75 & 4179.86 & 4086.1 & 1.06 & 0.87 \\
\hline 'New Bonnet' & -3.84 & 3703.38 & 4414.51 & 0.69 & 3998.82 & 3625.22 & 0.66 & -0.96 \\
\hline 'Vandana' & -0.45 & 540.68 & 3746.25 & 0.59 & 3724.39 & 3702.77 & 1.41 & 0.94 \\
\hline $\mathrm{HSD}_{0.05}$ & 1.78 & 1798.4 & 833.24 & 0.26 & 772.9 & 754.76 & 0.53 & 1.32 \\
\hline $\mathrm{LSD}_{005}$ & 3.52 & 3542.1 & 1641.1 & 0.52 & 1522.3 & 1486.5 & 1.05 & 2.61 \\
\hline
\end{tabular}

YP: yield of any genotype under conditions without stress, YS: yield of any genotype under drought stress conditions, SSI: sensitivity to stress index, TOL: stress tolerance index, MP: arithmetical mean index, STI: tolerance to stress index, GMP: geometric average index, HM: harmonic mean index, RDI: relative drought index, DRI: response to drought index, HSD: Tukey's Studentized Range and LSD: Least Significant Difference

\section{Conclusions}

Considering the results, dwarf cultivars showed good resistance to drought stress which is caused by more assimilates transfer to panicles. Also, tolerance to high stress in dwarf cultivars resulted from their smaller size and their growing period. In addition, since dwarf cultivars had higher yield than tall cultivars (Tab. 5), these cultivars can have advantage to dwarf cultivars under water deficit stress. According to cluster analysis, a breeded cultivar, namely 'Nemat', as the genotype with the highest average considering studied traits is suggested for hybridization with native cultivar, namely 'Domsephid', which had the lowest average considering studied traits. Since yield of 'Nemat' cultivar under conditions of drought stress ( $\left.5126.62 \mathrm{~kg} \cdot \mathrm{ha}^{-1}\right)$ was desirable (Tab. 5) and resistance indices to drought showed that 'Nemat' cultivar is resistant to drought, we can recommend this cultivar as superior cultivar for planting under conditions of drought stress.

\section{Acknoledgments}

Special thanks to the management, the faculty members and respectful staff of the Faculty of Agricultural Agronomy Sciences, Guilan University for their worthwhile helps to the implementation of this experiment. This research was financially supported by Researcher assistance and Graduate Studies Department of Guilan University.

\section{Refrences}

Bidinger FR, Mahalkshmi V, Rao GDP (1978). Assessment of drought resistance in millet. Factors effecting yields under stress. Australian J Agric Res 38:37-78.

Blum A (1996). Crop responses of drought and the interpretation 
of adaptation. Plant Growth Regul 20:135-148.

Fernandes GC (1992). Effective selection criteria for assessing plant stress tolerance, p. 257-270. In: Kuo CG (Eds.). Proceedings of the International on Adaptation of Vegetables and other Food Crop to Temperature Water Stress, Taiwan.

Fischedr RA, Maurer R (1978). Drought resistance in spring wheat cultivars. I: Grain yield responses. Australian J Agric Res 29:879-912.

Fukai S (1999). Phenology in rainfed lowland rice. Field Crops Res 64:51-60.

Fukai S, Cooper M (1995). Development of drought-resistant cultivars using physio-morphological traits in rice. Field Crops Res 40:67-86.

Guolan L, Hanwei M, Hongyan L, Xinqiao Y, Guihua Z, Lijun L (2010). Sensitivities of rice grain yield and other panicle characters to late-stage drought stress revealed by phenotypic correlation and QTL analysis. Mol Breeding 25:603-613

Janardhan KV, Krishnamoorthy V (1975). A rapid method for determination of osmotic potential of plant cell sap. Curent Sci 44(1):390-391.

Jongdee B, Pantuwan G, Fukai S, Fischer K (2006). Improving drought tolerance in rainfed lowland rice: an example from Thailand. Agricultural Water Management 80:225-240.

Kumar A, Singh DP (1998). Use of physiological indices as a screening technique for drought tolerance in oilseed Brassica species. Annals Botany 81:413-420.

Lafitte R, Blum A, Altin G (2003). Using secondary traits to help identify drought tolerant genotypes. In: Fischer KS, Lafitte R, Fukai S, Altin G, Hardy B (eds.). Breeding rice for drought-prone environment. International Rice Research Institute. Los Banos, Philippines.

Oak M, Basnayake J, Tsubo M, Fukai S, Fischer KS, Cooper M, Nesbitt H (2006). Use of drought response index for identification of drought tolerant genotypes in rainfed lowland rice. Field Crop Research 99(1):48-58.
Quizenberry JE (1982). Breeding for drought resistance and plant water use efficiency. In: Christiansen MN, Lewis CF (Eds.). Breeding Plant for Less Favorable Environments. Wiley-Interscience, New York.

Pantuwan G, Fukai S, Cooper M, Rajatasereekul S, O’Toole JC (2002). Yield response of rice (Oryza sativa L.) genotypes to different types of drought under rainfed lowlands. I. Grain yield and yield components. Field Crops Res 73:153-168.

Reddy AR (2009). Genomic approaches to improve drought tolerance in rice: Strategies and perspectives. IRRI.

Richards RA (1996). Defining selection criteria to improve yield under drought. Plant Growth Regulation 20:157-166.

Rosielle AA, Hamblin J (1981). Theoretical aspects of selection for yield in stress and non stress environments. Crop Sci 21:943-945.

Salekdeh GH, Siopongco J, Wade LJ, Gareyazie B, Bennett J (2002). Proteomic analysis of rice leaves during drought stress and recovery. Proteomics 2(9):1131-1145.

Serraj R, Cairns J, Atlin G, Bernier J, He H, Liu DC, Li ZK, Brar D, McNally K, Leung H, Herve P, Bruskiewich R, Bennett J (2009). Drought resistant rice:Physiological framework for an integrated research strategy. IRRI.

Sio-Se Mardeh A, Ahmadi A, Poustini K, Mohammadi V (2006). Evaluation of drought resistance indices under various environmental conditions. Field Crops Research 98(2-3):222-229.

Zhou GS, Jin DM, Mei FZ (2007). Effects of drought on rice grain indices at booting stage. J of Huazhong Agric Uni 3:219-222. 